\title{
Pedagogic Competency Analysis of Teachers in Indonesia
}

\author{
Rina Damayanti \\ SMP Negeri 1 Prabumulih \\ e-mail: rinayess23@gmail.com \\ Syarwani Ahmad \\ Universitas PGRI Palembang \\ e-mail: syarwaniahmad@univpgri-palembang.ac.id \\ Ahmad Wahidy \\ Universitas PGRI Palembang \\ e-mail: ahmadwhidy@univpgri-palembang.ac.id \\ Article History: Received on 1 December 2020, Revised on 8 January 2021, \\ Published on 21 January 2021
}

\begin{abstract}
This research was conducted through a qualitative approach. The method used in this research is descriptive method. The instruments used were observation sheets, interview guides, audio and video recording devices and teacher administrative documents. For data testing, data triangulation techniques are used. Furthermore, the data were analyzed using the following steps data collection; data reduction; data display, and verification and conclusion. The results showed that 1) the pedagogical competence of the teacher in managing the learning process at SMP Negeri 1 Prabumulih was classified as good; 2) the obstacles faced by teachers in managing the learning process are teachers' lack of understanding of the 2013 curriculum; scoring system; teachers only rely on textbooks or teacher handbooks in delivering learning materials without trying to find other relevant learning sources; lack of use of learning media; and teachers' inadequate ICT skills; 3 ) there has been no real effort made by the majority of teachers in overcoming obstacles faced in the management of the learning process.
\end{abstract}

Keywords: Pedagogic Competence, Learning Evaluation, Student Development

\section{A. Introduction}

Education is one important development sector for every country. This is because the progress of a nation can be measured by the quality of education of its people. Education is a planned effort to influence other people, both individuals, groups and communities to do what education practitioners expect (Murkatik et al, 2020). A nation will be developed if its people have high education. In order to create an education system that is able to answer future challenges, the Government, in this case the President and the DPR, established law number 20 of 2003 concerning the National Education System. Education has a role and strategic function in order to produce the children's creativity (Lian et al, 2018). All educational institutions in Indonesia have a duty and responsibility to build a generation that is potential and able to compete in the world market.

Professional teachers have a social responsibility manifested through the competence of teachers from social environment and have effective interactive skills. Human resources must be empowered in information technology to become professional teachers (Rahmadoni, 2018). 
Teacher competency standards include four main competencies; 1) pedagogical competence; 2) personality competence; 3 ) social competence; and 4) professional competence. If you pay close attention, the teacher's competence turns out to have an interrelated relationship in order to realize optimal teacher competence. One of the important components in improving the quality of education is the teacher. The role of teachers is very important in teaching and educating early childhood, as well as in advancing the world of education. The quality of early childhood and education depends on the quality of teachers. Teachers must find learning methods so that students participate actively in the learning process. Therefore, teachers must have competencies in accordance with SNP, in order to carry out their duties and roles properly and successfully. One of them is teacher competence, namely the pedagogical competence that every teacher must have in educating early childhood. All teachers are expected to have competency attitudes that meet national standards so as to create a good and advanced quality of education for Indonesia itself.

According to the National Education Standards Agency in Jejen (Musfah, 2012) what is meant by pedagogy is: Ability to cultivate students; (a) understanding educational insight or foundation; (b) understanding of students; (c) developing curriculum / syllabus; (d) instructional design; (e) educational and dialogical implementation; (f) evaluation of learning outcomes; and ( $\mathrm{g}$ ) develop students to actualize their potential. Based on the above description, the authors conclude that the education provided by the government is not in accordance with the expectations set forth in the National Education System Law Number 20 of 2003 Article 3. Therefore, it is necessary to have an alternative education model.

From the results of observations and based on initial reflection through discussions with teachers at SMP Negeri 1 Prabumulih City, student learning outcomes in science subjects are still not optimal. It can be seen that the average result of the Minimum Completeness Criteria obtained by students. Students do not understand science lessons, it is because in the learning process it is not interesting, boring, does not provide opportunities for students to be active and does not realize interactions between students so that students look bored when the learning process takes place. The learning method used is still oriented towards the teacher and does not involve student activities.

When viewed from the facts in the field that the learning system applied at SMP 1 Prabumulih is more dominated by conventional learning. Children tend to be passive because they only receive material and practice questions from the teacher. This is certainly not enough to support the mastery of the concept of science material for the better. The low level of mastery of the science concept which is controlled by the low scores of students' science learning outcomes. At SMP Negeri 1 Prabumulih, a science teaching and learning activity was held for a cycle carried out on August 1, 2018 in Class VIII.2 with a total of 35 students. In this case, the researcher acts as an educator. This learning process refers to the lesson plans that have been prepared. These observations are carried out simultaneously with the learning process. In the final process of teaching and learning students are given a formative test with the aim of seeing that students are in the learning process that has been done.

In practice, the teaching material presented by the teacher does not challenge students to think, as a result, students do not like the learning. No one knows the learning process that occurs in the classroom except the teacher himself. Coupled with the lack of functioning of school principals and supervisors. Principals are required to be able to have readiness in managing schools (Meidiana, 2020). Principals and supervisors as an integral part of the implementation 
Volume 1 (3) 2020

E-ISSN: 2723-6919 P-ISSN:2746-0827

of education in schools rarely enter the classroom to observe learning. Principals or supervisors generally place more importance on teacher administrative documents, such as study groups rather than going to class, observing and supervising learning. The role of the principal as a leader with his leadership style must be able to influence other people or subordinates must have good emotional intelligence (Asvio et al, 2019). The principal must be able to practice innovations, be able to direct all members and the school (Andriani et al, 2018). As a result, teachers feel less challenged to do teaching preparation well, think about various teaching methods, prepare materials for experiments in the laboratory. The principal faces greater challenges than the past in carrying out the duties and functions he plays on a daily basis (Komalasari et al, 2020).

The teacher thinks that their job is only to provide the knowledge they have with the target of delivering the topics written in the curriculum document. Curriculum innovation can be defined as deliberate actions to improve a learning environment by adopting a method of presenting material to students that involve human interaction, hands-on activities, and student feedback (Wachidi, 2019). In general, teachers do not inspire children to be creative and do not train children to live independently. The subject matter presented by the teacher does not challenge students to think, which consequently students do not like the lesson. To overcome these things the teacher needs to do lesson study, so that the teacher can repeat his performance which can then be used as input to improve his performance. Teacher performance will be optimal if it is integrated with school components, whether it is the principal or students.

In addition, other obstacles that arise in learning activities are learning tools and services in schools. Many factors affect teacher performance, both external and internal factors (Maryati et al, 2020). Learning tools in schools that are incomplete and comfortable cause students to have difficulty improving their learning outcomes. It also includes the means used by the teacher in implementing the methods that will be used in learning. The supporting facilities for teaching and learning at SMP Negeri 1 Prabumulih City can be said to be quite adequate, however to fulfill all class activities is still very minimal. Included in the means for preparing learning methods.

Professional teachers believed to be able to make student think, behave and act creatively (Ruslan et al, 2020). Because the ability of teachers is required to be professional in the field of teaching, in this study the author only examined SMP Negeri 1 Prabumulih City and the researchers only focused on science subject teachers where the author was one of 10 science teachers at SMP Negeri 1 Prabumulih City. This study only uses data and previous research as sources that need to be optimized, this study only intends to examine the level of pedagogical competence of junior high school teachers who add insights for writers and input for UPTD Pendidikan, Principals, Teachers of State Junior High Schools in Prabumulih.

Based on the description above, it can be shown that there are still obstacles related to teacher competence. Starting from the background of the problems above, the research about pedagogical competencies is important to be done.

\section{B. Methods}

This research was conducted in order to find out and the discussion was focused on the Pedagogical competence of SMP Negeri 1 Prabumulih City teachers. After determining the research location, the next informant was selected as the research subject. In qualitative 
Volume 1 (3) 2020

E-ISSN: 2723-6919 P-ISSN:2746-0827

research there is no original sample, but only purposive sampling. The determination of informants in this study used purposive sampling, in which the researcher determined the informants based on the assumption that the informants could provide the information the research wanted in accordance with the research problem through interview techniques. In other words, the selected informants are key informants with good knowledge of or involvement with the problems to be studied.

The method used in this study is a qualitative research method, which aims to analyze the Pedagogical Competence of Teachers of SMP Negeri 1 Prabumulih City. Qualitative techniques are used as an approach in this research, this is because these techniques are useful for understanding rational reality as subjective reality. The process of observation and in-depth interviews is very important in data collection. From the observations, it is expected to explore the stages of the Pedagogic Competence Analyst for Teachers of SMP Negeri 1 Prabumulih City.

\section{Results and Discussion}

\section{Competency 1: Knowing the Characteristics of Students}

Types and ways of assessing: Pedagogic Competence (Observation and Monitoring)

Statement: The teacher records and uses information about the characteristics of students to help the learning process. These characteristics are related to the physical aspects of intellectual, social emotional, moral, and socio-cultural background.

Based on the results of interviews with research informants above, it can be concluded that the characteristics of students in the dimensions of understanding towards students in the pedagogical competency analysis of SMP Negeri 1 teachers have not been implemented properly. Because of the many students in the classroom or at school, only a few students can understand their characteristics.

\section{Competency 2: Mastering learning theories and teaching learning principles.}

Types and ways of assessing: Pedagogic (Observation)

Statement: The teacher determines various approaches, strategies, methods and learning techniques that educate creatively in accordance with teacher competency standards. The teacher adjusts the learning method to suit the characteristics of students and motivates them to learn.

Based on the results of interviews with research informants above, it can be concluded that identifying the potential of students in the pedagogic competency analysis of junior high school teachers has been implemented well. This is shown by conducting tests to identify the potential that students have, so that teachers can more easily direct students in learning activities at school.

\section{Competency 3: Curriculum development}

Types and ways of assessing: Pedagogic (Observation)

Statement: The teacher prepares a syllabus according to the most important objectives of the curriculum and uses lesson plans according to the objectives and learning environment. The teacher selects, arranges, and arranges learning materials according to the needs of students. 
Volume 1 (3) 2020

E-ISSN: 2723-6919 P-ISSN:2746-0827

Based on the results of the interviews with the research informants above, it can be concluded that the learning objectives of the pedagogic competency analysis of the teachers of SMP Negeri 1 Prabumulih have been implemented properly. This is shown by the obligation of each teacher to formulate learning objectives that they will provide when carrying out teaching and learning activities in class.

\section{Competency 4: Educational Learning Activities}

Types and ways of assessing: Pedagogic (Observation)

Statement: The teacher prepares and implements the lesson plan which educates completely. Teachers carry out learning activities according to student needs. Teachers compile and use various learning materials and learning resources according to student characteristics. If relevant, teachers make use of information communication technology (ICT) for the benefit of learning.

Based on the results of interviews with research informants above, it can be concluded that compiling a lesson plan on the pedagogical competency analysis of teachers at SMP Negeri 1 in Prabumulih City has not been implemented properly. The principal does not pay much attention to how the teacher compiles lesson plan, the important thing is that there is a report. The teacher will usually use the previous year's lesson plan. Understanding is usually only in the way of delivering the material and understanding the material.

\section{Competency 5: Understand and develop potential} Types and ways of assessing: Pedagogic (Observation and Monitoring)

Statement: The teacher analyzes the learning potential of each student and identifies the development of the potential of students through learning programs that support students to actualize their academic potential, personality, and creativity until there is clear evidence that students actualize their potential.

Based on the results of the interviews with the research informants above, it can be concluded that designing creative learning on the pedagogic competency analysis of junior high school teachers has not been implemented properly. There are still educators who give lessons using the previous year's method even in a very unpleasant atmosphere. Where students feel a stiff atmosphere and make themselves sleepy. Later this will have an impact on the quality of student learning.

\section{Competency 6: Communication with Students}

\section{Types and ways of assessing: Pedagogic (Observation)}

Statement: The teacher communicates effectively, emphatically and politely with students and is enthusiastic and positive. The teacher provides a complete and relevant response to student comments or questions.

Based on the results of interviews with research informants above, it can be concluded that communicating well in the dimensions of the implementation of learning in the pedagogic competency analysis of junior high school teachers has not been implemented properly. This is indicated by the existence of educators who do not use learning media so that the communication provided is better for students, even though the teacher has been given guidance on good communication. In addition, teachers are still authoritarian towards students, so they feel they are not in a pleasant atmosphere to learn. 


\section{Competency 7: Assessment and Evaluation}

\section{Types and ways of assessing: Pedagogic (Observation)}

Statement: The teacher conducts an assessment of the process and learning outcomes on an ongoing basis. The teacher evaluates the effectiveness of the process and learning outcomes and uses the information from the assessment and evaluation results to design remedial and enrichment programs. The teacher uses the results of the assessment analysis in the learning process.

Based on the results of the interview above, it can be concluded that the indicators of compiling learning evaluation questions in the pedagogical competency analysis of SMP 1 teachers in Prabumulih have not been implemented properly. This can be seen from the failure to implement plans in the field of coaching and training in writing (compiling) learning evaluation questions. So that the personnel involved in handling the preparation of evaluation questions do not master the rules of technique for preparing the items. There are even teachers who only make questions based on the previous year's exam questions and only change some of the questions that are considered too easy without analyzing the items and making them into the next lesson plan.

\section{Conclusion}

Based on the results of research and discussion of the pedagogical competency analysis of teachers of SMP Negeri 1 in Prabumulih City, the following conclusions can be drawn: 1) in the dimension of understanding towards students, indicators that have been implemented well are identifying student potential. Meanwhile, the indicators for student characteristics are still not well implemented. This can be seen from the many students in the classroom or at school, only a few students whose characteristics can be understood by the teacher; 2) in the learning planning dimension there are still weaknesses in indicators in the preparation of learning designs and designing creative learning. In preparing the lesson plan, the teacher sometimes only copies from the previous year's learning plan. Including in designing creative learning, there are still teachers who give lessons using the previous year's method even with an unpleasant atmosphere; 3) in the implementation dimension, indicators that are still weak are indicators of good communication. This is indicated by the existence of educators who do not use learning media so that the communication provided is better for students; 4) in the student development dimension, all indicators show that they have been implemented well. The facilities at school really support student activities. The teacher also actively encourages students to participate actively in every activity so that they are expected to develop students' potential optimally, and 5) in the learning evaluation dimension, indicators that are still weak are indicators of preparing learning evaluation questions, where no plans have been realized in the field of coaching and training in writing or compiling learning evaluation questions to teachers. It also includes indicators using the results of the assessment to improve learning. The teacher only makes questions based on the previous year's exam questions and only changes some of the questions deemed necessary without using the results of the assessment to improve lessons and subsequent evaluation questions.

\section{E. Acknowledgement}

Our deepest gratitude goes to the Principal of SMP Negeri 1 Prabumulih, Chancellor of the PGRI Palembang University, Director of the PGRI Palembang University Postgraduate Program and the PGRI Palembang University Education Management Study Program who 
Volume 1 (3) 2020

E-ISSN: 2723-6919 P-ISSN:2746-0827

have supported us to do this extraordinary thing. This project is independently funded. We would also like to thank our friends in Education Management who helped us a lot in completing this project in a limited time frame.

\section{References}

Andriani, S., Kesumawati, N., \& Kristiawan, M. (2018). The Influence of the Transformational Leadership and Work Motivation on Teachers Performance. International Journal of Scientific \& Technology Research, 7(7).

Asvio, N., Yamin, M., \& Risnita. (2019). Influence of Leadership Style, Emotional Intelligence and Job Satisfaction toward Organizational Commitment (Survey at SMA Muhammadiyah South Sumatera). International Journal of Scientific \& Technology Research 8 (8).

Komalasari, K., Arafat, Y., \& Mulyadi, M. (2020). Principal's Management Competencies in Improving the Quality of Education. Journal of Social Work and Science Education, 1(2), 181-193. Retrieved from https://ejournal.karinosseff.org/index.php/jswse/article/view/47

Lian, B., Kristiawan, M., \& Fitriya, R. (2018). Giving Creativity Room to Students through the Friendly School's Program. International Journal of Scientific \& Technology Research, 7(7).

Maryati, E., Fitria, H., \& Rohana, R. (2020). The Influence of Principal's Leadership Style and Organizational Culture on Teacher's Performance. Journal of Social Work and Science Education, 1(2), 127-139. Retrieved from https://ejournal.karinosseff.org/index.php/jswse/article/view/38

Meidiana., Ahmad, S., \& Destiniar. (2020). Pengaruh Kompetensi Manajerial Kepala Sekolah dan Supervisi Akademik Terhadap Kinerja Guru [Effect of Principal Managerial Competence and Academic Supervision on Teacher Performance]. Jurnal Manajemen, Kepemimpinan dan Supervisi Pendidikan 5(2), Juli-Desember, 2020.

Murkatik, K., Harapan, E., \& Wardiah, D. (2020). The Influence of Professional and Pedagogic Competence on Teacher's Performance. Journal of Social Work and Science Education, 1(1), 58-69. Retrieved from https://ejournal.karinosseff.org/index.php/jswse/article/view/10

Musfah. (2012). Peningkatan Kompetensi Guru Melalui Pelatihan dan Sumber Belajar Teori dan Praktik. Jakarta: Kencana.

Rahmadoni, J. (2018). Perancangan Simulasi Pembelajaran Kriptografi Klasik Menggunakan Metode Web Based Learning. INTECOMS: Journal of Information Technology and Computer $\quad$ Science, $1(1)$,

34-43. https://doi.org/https://doi.org/10.31539/intecoms.v1i1.160 
Journal of Social Work and Science Education

Volume 1 (3) 2020

E-ISSN: 2723-6919 P-ISSN:2746-0827

Ruslan, Lian, B., \& Fitria, H. (2020). The Influence of Principal's Situational Leadership and Teacher's Professionalism on Teacher's Performance. International Journal of Progressive Sciences and Technologies (IJPSAT), 20(1).

Wachidi. (2019). Teachers' Stage of Concern in Implementing Elementary School Curriculum Innovation. International Journal of Educational Review Vol. 1, Issue. 2, 27-34. Retrieved from https://ejournal.unib.ac.id/index.php/IJER/article/view/8843 